\title{
A PHEASANT VENTURE
}

By Arthur Ward, Swift Current

$W$ JHAT was that? My attention as I skirted the spruce trees was arrested by seeing a smudge in the snow the two sides edged with streaks made by wings alighting, and footprints proceeding from there, larger than those of the Hun. Partridge.

I put out feed, curious to know more about our visitor. It proved to be a hen Pheasant. This could be considered a rarity in our district. Feed placed to keep it under observation induced it to stay. Along came spring and during May search revealed the Pheasant with a nest of five eggs-of course infertile.

I wrote a letter to the then Provincial Game Commissioner in Regina, Mr. Ed. Forsythe, asking him if he could supply me with a male Ring-necked Pheasant. I had this in my possession the next day. To accomplish this he had phoned the superintendent of the Moose Jaw Wildlife Park. A train about to pull out from Moose Jaw to Neidpath was caught and the railway foreman from Burnham happened to be there when it arrived. I surely was surprised when the foreman phoned me to come and get the Pheasant, within twenty-four hours after asking for it.

I clipped a little off the wing and soon the two Pheasants were seen together. The nesting site was poorly chosen on the side of the ditch of the highway. After laying seven eggs I found our Pheasant flattened out on the road by the heavy traffic. Soon after this the male disappeared.

I put the eggs under a setting hen. Three young were hatched and placed in a pen and kept there over winter. The male and two females were afterwards placed in the grove.

I had intended keeping a selection of the increase penned up during the winter. About four one windy afternoon in the fall a stray cat was observed going into the grove. The next day there was not a Pheasant to be seen. They were found located along the banks of the creek and the vicinity of the Highfield Dam.
From enquiries made, they eventually reached the number of one hundred and were seen feeding with the farmers' chickens. One day, going across the creek I felt that my efforts had not been in vain, for I observed a beautiful cock Pheasant walking across the road ahead of the car.

The pheasant observation was short lived. The former winters, mild and with little snow, were followed with a succession of severe winters with deep snow, rendering the thick and natural bush undercover ineffective. Thus our Pheasant venture gradually faded out. It cannot be disregarded that the habitat is the most important thing in establishing and retaining species indigenous where disturbing factors of the ever encroaching cultivation methods have not kept pace in the rehabilitation of wildlife effected.

\section{Winter Birds Scarce William Niven, Sheho}

THE number of species and individuals among the birds was smaller than usual this winter. It was a poor season for seeing them around here anyway. Sharp-tailed Grouse were in much lesser numbers than last winter. Some days ago I saw sixteen but by Christmas birdcount time they must have moved to other districts. The Woodpeckers and Chickadees were fewer in number, too. This may be because much of the heavy bush has been cut off our place. No Bohemian Waxwings were observed this season and very few Evening Grosbeaks earlier in the winter. The Pine Grosbeaks, also, were very scarce, only very small groups, up to about ten, having been seen. A very few Common Redpoles were seen from time to time. The Snow Buntings also were scarce during the winter. The flocks I have seen were much smaller than the usual large numbers present some winters. 